\title{
The Federal Information Controversy from an Economic Perspective
}

\author{
Thelma Freides
}

Currently controversial issues about the production and distribution of information by the federal government relate to broader questions about the appropriate scope of governmental services and the boundaries of public and private enterprise. Concepts derived from the economic analysis of public expenditures provide a framework for examining the purposes of federal information activities and the advantages and drawbacks of various organizational and financing arrangements. Cost-benefit analysis techniques should be explored and developed as assessment tools in the field of government information.

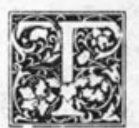

here are three key issues in the current conflict about federal information policy:

1. What information should the federal government make available to the public?

2. Should government information be transmitted to the public via governmental or private means?

3. Should the costs of transmission be borne by the public at large or by the users of the information?

The questions are long-standing, but the controversy has heated up during the past few years as a result of several converging factors.

The Reagan administration propounds a governmental philosophy that departs in significant ways from previous administrations. A central aim is to reduce social intervention by government. This has the effect of reducing the government's information output, because data collected to guide policy are no longer needed when the policy area is removed from the range of governmental concerns. It also inhibits the provision of information as a government service to the public. In addition, there is a heightened concern with control of the information reaching the public, a concern that is manifested in restrictions on public access to information in the government's possession.

Concurrently, there is an expanding information market, abetted by technological advances. Availability of information by electronic transmission opens new avenues of dissemination and increased profit possibilities for the private information industry. This development coincides with the Reagan administration's inclination to reduce the scope of government by placing as many functions as possible in the hands of the private sector. The results are less government output of information, more restricted access to government files, transfer of information activities formerly conducted by government agencies to private firms, and higher charges to information users, ${ }^{1}$

Thelma Freides is Head, Reader Services, at State University of New York, Purchase, New York 10577.

The author wishes to thank Jacob J. Kaufman for helpful suggestions concerning the economic concepts discussed in this paper. 
The library community's strong and unequivocal opposition to these trends has been grounded mainly in appeals to democratic values. In the United States there is a basic presumption, buttressed by both law and tradition, of public access to information created or held by the federal government, with minimal restraint. ${ }^{2}$ It is deemed an essential precondition of democratic government for citizens to be able to discover, and thus to judge, what the government is doing. Any general restriction is seen as objectionable, and economic restrictions particularly unjustifiable because they violate the basic equality of citizens. Proceeding from this orientation, the American Library Association has repeatedly "reaffirmed its long standing conviction that open government is vital to a democracy."

\section{THE PROBLEM}

The open government argument is valid and persuasive, but it leaves some important questions unaddressed.

First, information distributed by government includes both information about government and information about other matters disseminated as a government service to the public. The former group consists essentially of byproducts of other government activities, and includes documents generated by the legislative process, the administrative and regulatory records of government agencies, and statistics and other data collected to inform policy decisions. Democratic values support an assertion that this is public property and all citizens are the owners, possessing proprietary rights to acquire and use the information their government has created. But other information is made available as a government service, created and distributed by government only for the purpose of aiding people in their private pursuits. The Government Printing Office best-seller Infant Care ${ }^{4}$ is a classic example.

Many government publications are issued to help people, in one way or another, earn a living through better farming or business practices. The critical question becomes, what is the appropriate extent of this kind of government service? Answers are cast in terms of the social benefit re- sulting from a particular information activity, rather than the requirements of a democratic government and the rights of its citizens.

A second problem is that to assert a right of access does not deal with questions about the resource allocations required to make the right effective. If citizens have the right to use governmental information, do citizens have a corresponding obligation to provide the means of access as taxpayers? Is this obligation limited by the magnitude of the costs involved, by the number of people who benefit as compared with the number who have to pay, or by the private gain made possible from information provided at the taxpayers' expense?

These questions touch a much broader issue than information policy: establishing equal rights in an economically unequal society. Rights are, by definition, "distributed universally and equally and free of charge to all adult citizens." embody values that are deliberately placed beyond the range of economic distinctions, because "society refuses to turn itself into a giant vending machine that delivers anything and everything in return for the proper number of coins. ${ }^{116}$ Nonetheless, "any entitlement is more likely to be established as a right when it has relatively low resource costs. . . . It is much less expensive, in every sense, to fulfill the right to free speech than a 'right' to free food."

Considerations of this kind probably underlie the question posed by the Ad Hoc Advisory Committee on Government Publications in its report to the Congressional Joint Committee on Printing:

Should the information generated by the government be considered as an economic good to be dealt with in purely economic terms, or as a social good to be dealt with in purely social terms, or a combination of both? ${ }^{8}$

This formulation has been echoed in other discussions of Reagan administration information policies, ${ }^{9}$ but asking the question in this way gives no help at all toward an answer. It is unlikely that any government activity can be dealt with in purely economic terms, because government actions in the economic sphere are 
almost always intended to alter economic relationships to serve social ends. Yet, no matter how socially desirable an activity may be, it consumes resources that are thereby unavailable for other uses, and there is no way to avoid asking whether a given use of a resource is superior to other uses, which is to deal with the question in economic terms. Likewise, where the social gain resulting from an activity does not flow universally and equally to all, there is no way to avoid another economic question, which is who benefits and who pays. Obviously, the answer to the Ad Hoc Committee's question is "a combination of both," but what sort of combination?

\section{THE ECONOMIC PERSPECTIVE}

In several important respects the federal information issue is a particular case of the broad constellation of questions having to do with government's responsibility to provide for the needs of the population and society's arrangements for adjusting economic relationships to conform to social values. Questions of this type are examined extensively in the economic literature on public expenditures in which two basic propositions are generally encountered: ${ }^{10}$

1. Government intervention in economic processes stems from a discernible rationale and follows certain patterns in order to achieve defined goals. The appropriateness of the intervention is judged in relation to the goal and the various possibilities for achieving it.

2. Intervention by government means that resources are usually not allocated the same as resources in the free market. The use of public funds does not mandate any particular form or agency of production or distribution, e.g., public or private, or any particular allocation of costs. Many organizational and pricing arrangements are possible. Their desirability varies relative to other factors.

What follows is an examination from an economic perspective of the three key federal information issues enumerated at the outset of this paper. While economic analysis will not resolve the government information controversy, it does provide a use- ful tool for identifying ends and means, and for sorting out the assumptions and choices underlying policy issues.

\section{CONDITIONS OF PUBLIC INTERVENTION INTO MARKET ALLOCATION}

The normal expectation in market economies is that the market allocates resources to the production of goods and services in response to consumer demand. The aggregate of economic choices made by individuals in accordance with their personal priorities and preferences produces the most efficient allocation of resources for the economy as a whole, i.e., maximum output for a given input. Government intervenes in the market, replacing individual consumer choice with collective political choice, when the market is unable to make the necessary allocations, or when market allocation contravenes goals other than efficiency. This occurs under the following circumstances: ${ }^{11}$

\section{Collective Goods}

These are goods and services whose use cannot be confined to those who pay for them, because once produced they are equally available to all, e.g., national defense, flood control, street cleaning, and lighthouses. Because there is no way to prevent the free use of such goods, the market cannot determine their value or the quantity to be produced. Government therefore allocates these resources by political decision and people are taxed to pay for them. In economic language, the ability to limit access to a good to those who pay for it is called the exclusion principle. Collective goods by their nature cannot be subject to the exclusion principle.

\section{Economies of Scale; Monopolies}

Some goods and services cannot be supplied successfully by the free market because no competition exists. For products requiring extensive capital investment, the cost per unit may decrease as the quantity produced increases, e.g., gas and electric power generation, rail transit, and water and sewage systems. Production yields the most output for the least cost if there is only one producer; however in 
monopoly situations there is no market mechanism to limit the price the monopolist is able to charge. Government therefore awards the field to a single producer and controls the price through a regulatory process (public utility franchises and rate-setting commissions) or by direct government operation of the enterprise (municipal water and transit systems.)

\section{Externalities, or Spillover Effects}

Some goods have important effects on people who are not consumers. Fire protection could be limited to property owners who pay for it, but when a fire in a nonpayer's house is extinguished others benefit. Education confers increased earning power on those who receive it, but employers also gain from a literate, hence more productive labor force, and the benefits of a more productive economy accrue to the society at large. Projects requiring very large or long-term investment may yield indirect returns that investors cannot recoup. By increasing the revenues of hotels and restaurants a convention center yields returns in excess of its direct revenues. Thus, the project may be worthwhile as a public venture even if it would not be sufficiently profitable as a private venture. Basic scientific research may eventually yield large profits from commercial applications, but this research is often undertaken by government because the gains are too distant or uncertain to attract private resources.

The difference between the total value of a good and its market value is described by the term externality or spillover. Externalities can be negative as well as positive, representing costs as well as benefits. Industrial pollution is a negative externality, meaning that the market has no way to impose that cost of production on the polluter. The government intervenes to make the necessary adjustment by tax or regulation. Externalities are not necessarily or exclusively monetary. An architecturally beautiful building, for example, benefits all who view it, in addition to those who pay rent to occupy it. In such circumstances private owners normally charge the aesthetic contribution to philanthropy or public relations. Government some- times imposes aesthetic considerations on market calculations through zoning or laws protecting landmark buildings.

To summarize, where productive processes generate significant externalities, government commonly intervenes to fill the gap between the value of the good to single consumers and its value to society as a whole. In some instances the exclusion principle is disregarded and the good or service is made available to all without charge, becoming, in effect, a collective good, as in the case of fire protection or public elementary education. This tends to occur when consumption of the good is spread more or less equally through the population. Where consumption is not universal or equal the good is likely to be sold, but at a price below the cost of production, as in the case of public transit or public universities.

\section{Income Redistribution}

Many goods and services are provided by government in order to bring about a more equitable distribution of income than results from market forces. Income transfers of all kinds, such as farm subsidies, public housing, low-interest loans, and tax expenditures, come under this heading. Such redistribution almost always creates a positive externality, in that the benefits, e.g., a more prosperous economy, social peace, or scientific progress, accrue to the whole society as well as to the direct beneficiaries.

There is a fairly clear difference in emphasis, however, and for present purposes it is useful to place government expenditures aimed at bringing about production of goods that are not profitable for the private market in the externalities category, and to attribute those intended to redistribute access to goods that are, or can be, available in the private sector to income redistribution.

\section{CONDITIONS OF PUBLIC INFORMATION PRODUCTION}

Of the four concepts identified as bases for government economic interventioncollective goods, economies of scale, externalities, and income redistributionthe latter two are most relevant to 
information production. Very few, if any, information products are true collective goods, as it is just about always possible to limit consumption to those who pay. Some information is produced under conditions resembling monopoly, in that the market is too small to support more than one producer, but the possibility of economies of scale is outweighed by free speech considerations, so the public utility model is not normally seen as applicable. (This model may have some relevance to information distribution, as distinguished from production, and will be considered from that perspective in connection with privatization and pricing issues.)

The bulk of government information activity is accounted for by the concepts of externalities and income redistribution. It was postulated earlier that access to government records is a necessary condition for operation of a democratic political system. Availability of these records generates externalities: that is, benefits accrue not only to those who actually consult the records but to all citizens, because all benefit from the existence of open, democratic government. Similarly, availability of statistical data derived from censuses and surveys improves decision making in all spheres. This compares to the manner in which education contributes to increased productivity. Thus, even though there are highly profitable commercial uses of census data, the value to society as a whole is considered to be greater than the market value. Because of this difference, the production of censuses and other large-scale statistical projects is undertaken by government rather than left to private initiative.

Information activities directed toward income redistribution make available without charge, or at lower cost, information that can also be purchased on the private market. Infant Care is an example, as are many of the "how to" publications addressed to farmers, business people, homemakers, and so forth.

Again, the externalities and income redistribution categories, while different, overlap. All income redistribution activities are undertaken in the belief that they provide benefits to the society at large, and from that perspective are simply a variant of the externalities concept. It is nonetheless important to distinguish between information products that are uniquely governmental and those that have counterparts in the private sector, because the distinction provides a basis for conceptualizing government information activities in relation to the ends they serve.

For example, government statistics on such matters as wages, strikes, and occupational injuries are widely used in labormanagement relations. It might be asked why those who use the information do not provide it for themselves, i.e., buy it from data collection companies who could do what the government does now, which is to tabulate and distribute data reported from the private sector. That might, it is true, place labor at a disadvantage relative to management, and if the government's purpose in producing the statistics is to keep the price low, that is a case of income redistribution. A more fundamental consideration, however, is that statistics produced by the private sector are qualitatively not the same as government's. Only government has the ability through trust, legal coercion, or both to elicit the comprehensive response that statistical accuracy requires, and acceptability of governmental data to contending economic interests rests to a considerable extent on government's unique status as a disinterested neutral party. Both business and labor interests cite these reasons, more than cost or ability to pay, in support of government statistical programs.

The Medline/Excerpta Medica controversy provides a similar example. Critics of Medline and the other bibliographic enterprises of the National Library of Medicine hold that government services are produced under heavily subsidized conditions and thereby compete unfairly with privately produced services such as Excerpta Medica. ${ }^{13}$ Defenders of Medline counter that Excerpta Medica's real competitive disadvantage is not its higher price but Medline's qualitative superiority, which derives from the unique resources and expertise of the National $\mathrm{Li}$ brary of Medicine and cannot be matched 
by a private competitor. ${ }^{14}$ Assuming that Medline is indeed priced below its cost of production (a point that is neither conceded by the defenders nor demonstrated by the critics) that still leaves the question of what the public subsidy buys: access to medical data for researchers who otherwise could not afford to buy it, i.e., income redistribution, or availability of medical data at a quality level that otherwise would not exist for anyone, i.e., externalities.

Distinguishing the concept of externalities from that of income redistribution is also useful in relation to the pricing of government information services. If the aim of the government activity is to create a product that would otherwise not exist, it is reasonable to expect the users of the product to support its cost in relation to the value received. If the aim is income redistribution, it is reasonable to allocate the costs on the basis of ability to pay. The matter will be examined more closely in the discussion of cost allocation.

\section{COST-BENEFIT ANALYSIS AS A DECISION-MAKING TOOL}

The foregoing review of government economic intervention suggests that the answer to What information services should the government provide? is: those that yield a social benefit in excess of the return that can be expected in the market. However, this answer only establishes the plausibility of such an activity. Its necessity is not established nor is a way suggested for choosing among competing alternatives.

Decisions about the allocation of resources generally involve comparison of costs and expected returns, and the chosen alternative is generally the one that offers the largest margin of value over cost. In private economic calculations, value corresponds to the price paid in the market. Because government expenditures are undertaken precisely where market prices cannot guide the allocation of resources, the value, or expected return, of a project must be estimated on some other basis. Cost-benefit analysis is the term used to denote a set of techniques employed for measuring the value of public projects.

The cost-benefit concept is sometimes disparaged as a rationalization for government inaction or retrenchment. "Anyone with any knowledge of cost-benefit analysis knows how much hocus-pocus there is in this kind of numbers-juggling. It is relatively easy to come up with cost figures, but very difficult to measure benefits. ${ }^{\prime 15}$ Many librarians apparently subscribe to this view, ${ }^{16}$ but what the argument lacks is an alternative to "numbers-juggling." All government projects are assumed to yield a surplus of social benefits over costs but if the benefit cannot be measured, how can one know that a surplus is really there?

Government information is quite vulnerable in this respect because there is almost no hard knowledge about its use and purported social benefits. Additionally, there is a strong, albeit impressionistic, perception of "widespread lack of appreciation of the potential value of documents. ${ }^{\prime 17}$ A decision by the Government Printing Office in 1982 to eliminate stocks of publications selling fewer than fifty copies annually was criticized by librarians, ${ }^{18}$ but it was at least an attempt to relate a public expenditure to evidence of public benefit. To argue against the decision one would have to assert that keeping the publications available, even at low levels of demand, is worth the cost of storage, and the question is whether such arguments are to be based on evidence of any sort, or only "unsupported opinion and emotive rhetoric. ${ }^{\prime 19}$ Viewed from this perspective, out-of-hand rejection of costbenefit approaches may be a greater threat to the unfettered flow of government information, especially in the long run, than the "shrink government" proclivities of the Reagan administration.

Because quantitative measurement facilities comparison, cost-benefit techniques generally attempt to quantify benefits whenever possible, usually by postulating some monetary surrogate for the government service in question. For example, the value of public recreational facilities might be partially equated to the price people are willing to pay for use of comparable private facilities. ${ }^{20}$ This does not mean that factors lacking obvious monetary equivalents are disregarded and that only money counts. "There is ... 
nothing wrong in quantifying the quantifiable and leaving the qualitative factors in list form for consideration by the decision maker." ${ }^{21}$ The critical point is the need for detailed scrutiny of all the factors entering into a decision. "At the very least, such a process enables attention to be focused on the question of whether the unmeasurable benefits are deemed impressive enough to justify sustaining the measurable costs that they entail.'

\section{PRIVATE VERSUS PUBLIC DISTRIBUTION OF GOVERNMENT INFORMATION}

Economic intervention by government means only that resources are allocated to the production of goods and services by collective political decision, rather than by individual demand in the marketplace. Governmental intervention does not require that government actually produce the product, and normal government practice admits a range of possibilities. Some goods and services are provided directly by government, e.g., public housing; some are purchased by government from the private sector for public use, e.g., military weapons and uniforms, surplus farm products. Government sometimes gives consumers funds for purchases in the private market, e.g., housing vouchers, food stamps, and sometimes pays the bills incurred by consumers in the private market, e.g., Medicare.

In the information debate, the private sector argues for a general presumption in favor of private over public distribution channels for government information. The position is grounded in Bureau of the Budget Circular A-76, the definitive policy statement on federal and private sector economic activities promulgated initially during the Johnson administration. Circular A-76, enunciating "the Government's general policy of relying on the private enterprise system to supply its needs," actually covers only goods and services procured for government use and excludes government services provided to the public. ${ }^{23}$ More recently, Office of Management and Budget Circular A-130, issued in December 1985 under the title "Management of Federal Information Resources," ex- plicitly extended the A-76 principles to the information field. ${ }^{24}$ While the circular's language is general enough to allow varying interpretations, there are several statements to the effect that federal agencies are expected to disseminate their information products via the private sector unless there are clear and compelling reasons not to, and are to refrain from undertaking information activities that the private sector is ready to perform. ${ }^{25}$ Although a blanket preference for private over public enterprise is essentially an ideological rather than an economic judgment, some economic considerations are relevant.

Circulars A-76 and A-130 provide that services purchased by government from the private sector are not to cost the taxpayers more than the same activities performed by government. ${ }^{26}$ Private-sector advocates allege that governmental costs are habitually understated because relevant items are absorbed into general governmental operations. ${ }^{27}$ Comparative cost calculations should include not only the government's direct expenditures but also less obvious items such as interest costs of invested capital and tax revenues that would be generated by private operations. "The real cost of a thing is what one must do without in order to get that thing, ${ }^{\prime \prime 28}$ or the most highly valued alternative use of the resource in question, and the "hidden" costs of a public enterprise are as much a charge on the public as actual dollar outlays.

This line of reasoning suggests an additional consideration. The private purveyor of government information is provided at public expense with the raw materials that are a normal charge on any business. In itself this is not a factor in comparing costs of government and private dissemination (assuming that the public bears the expense of creating the information because of positive externalities), but there is no reason to assume that the entrepreneur receives the public resource as an unconditional gift in perpetuity. The government has an obligation to protect the public interest by monitoring the cost of access to public information disseminated through private channels. There is no more justification for the government 
to turn over an information resource to a private entrepreneur for distribution without specifying the pricing arrangements than there would be for a city to franchise electric power distribution or public transit without provision for rate regulation. OMB Circular A-130 acknowledges the point, admonishing agencies to "take care that they do not permit contractors to exercise monopolistic controls, ${ }^{\prime 29}$ but there is evidence that the instruction is not always followed. ${ }^{30}$ Government may also use quite legitimately the prospect of its own entry into the market as a means to ensure the economic use of resources created at public expense. ${ }^{31}$

Cost comparisons necessarily assume that identical products are being compared, yet this may not always be the case for governmentally and privately produced information products. The qualities of economic statistics and medical bibliographic services that may be uniquely governmental were mentioned earlier. Historically, dissatisfaction with the private publication of government records led to the establishment of the Government Printing Office. ${ }^{32}$

There are other possible qualitative differences. It has been suggested that government dissemination carries the risk of government control and manipulation of information reaching the public, and also that private enterprise is more innovative than government. ${ }^{33}$ The presence or absence of competition is relevant to both points. In situations that do not lend themselves to competitive arrangements, a single private producer exercises the same control as government, and is normally less subject to accountability constraints in the form of open records, prescribed and formalized decision-making procedures, and legislative oversight. Similarly, if government bureaucrats are necessarily cautious about risking public funds on untried ventures, ${ }^{34}$ incentives to innovate in the private sector are greatest where many firms compete for a given market. Where a single seller dominates, incentives to risk are correspondingly reduced, and where government is the only customer for private producers working under contract, the effects of bureaucratic caution should be much the same as in a government enterprise.

The point is that governmental and private information services are not necessarily interchangeable, and the effect of public or private operations on the quality of the information is as relevant a consideration as cost or doctrine.

\section{COST ALLOCATION}

Suggestions to sell government information are likely to encounter the objection that people should not have to pay for access to government information that their taxes paid to create. ${ }^{35}$ The economic flaw in this argument is the assumption that the cost of information is equivalent to the cost of producing it. In reality there are distribution as well as production costs, which means that no matter who may have paid to create the information, the costs of distribution must also be paid. When information is distributed without charge, all citizens pay twice, sharing through their taxes the costs of both production and distribution. When government information is sold, direct users pay twice, for production via taxes and again for distribution via user charges, but the public pays only for production. In fact our society is replete with tax-created assets for which taxpayers are required to pay twice, e.g., toll roads and bridges, national parks, and public universities. It may be argued that information should not be subject to user charges even if parks and universities are, but user charges are not wrong in principle simply because tax dollars have created the asset in question.

Some writers assert a right to be informed as essential for "'the citizen's knowledgeable participation in the democratic process. ${ }^{136}$ Without further qualification it is difficult to see free distribution of government publications as the most effective way to advance such a right. As noted earlier, a great many government publications have little or nothing to do with public policy and the issues of the day. Moreover, the well-informed citizen depends as much on reports and commentaries from nongovernmental sources as on information supplied by government. The goal of raising the information 
level of the public would probably be better served by free distribution of newspaper subscriptions, or at least larger subsidies to public libraries, than by blanket free distribution of government publications.

A case for the free distribution of some government information as a requirement of the democratic process can be formulated on the basis of the concept of externalities. As stated earlier, goods and services that confer large social benefits, and are consumed more or less equally by everyone, tend to be turned into collective goods and made available to all without charge. By similar reasoning, the most important benefit of the availability to the public of the records of government actions and policy deliberations is the existence of the open, democratic society that depends on open records. Because the benefits of the open society are equal for all, the personal benefits to individuals who actually consult the government records may be seen as relatively incidental. This argument is applicable to the public records reflecting governmental decisions and the processes of policy formation, materials whose principal use outside of government is for investigation and assessment of governmental behavior. The point is weaker, though tenable, when applied to general social data, such as census materials, which, though widely employed for private purposes, figure importantly in the conduct of public business. With respect to the many publications used mainly by individuals in their private capacities, including the government's large output of scientific and technical reports, it does not seem unreasonable that those who benefit the most should bear the largest share of the cost. It may be desirable to ensure that insufficient funds are not a barrier to access, but that is an argument for income redistribution rather than equal access per se, and raises the question of whether that goal is best achieved by free distribution of the information to all users, or by direct subsidy of those unable to pay.

The crux of many contentiousprivatization and user-charge issues is the effect on depository libraries; specifically, whether information should be available without charge to depositories. There is a tendency to equate free access to government information with free distribution of government publications to selected libraries under the depository system. ${ }^{37}$ In reality, some distance separates free and equal access from current depository arrangements.

First, the depository system does not eliminate economic inequality as a differentiating factor in access to government publications. Libraries determine the extent of their depository collections and bear all the staffing and operating expenses. This means that citizen access to government information in depository libraries varies with the wealth of the particular institution housing the depository and its assessment of the value of government information relative to its other concerns.

Second, although open to all, depository collections and services are principally directed to a small minority of the population. Most depositories are in academic libraries and select the publications they receive in response to academic requirements. Although the logical information conduit for the public at large is the public library, fewer than one-quarter of the depositories are in public libraries. ${ }^{38}$

Third, the distribution of publications to depository libraries omits some information in federal hands to which the public has a right of access, but a right that is heavily qualified by economic considerations. For example, under the Securities Act of 1933 and the Securities Exchange Act of 1934, corporations are required to report certain financial information to the Securities and Exchange Commission. Likewise, under the Federal Election Campaign Act of 1971, candidates and political committees are required to file financial reports with the Federal Election Commission. In both cases the reporting requirements were enacted expressly to expose activities to public scrutiny, but the public's only access to the information is by traveling to Washington to inspect the records or purchasing the data from private suppliers. Government files are open equally to all under the Freedom of Infor- 
mation Act but those unable to pay the costs of such inquiries cannot have recourse to depository libraries as an alternative.

Historically, it does not appear that any clear goal or purpose was ever specified for the depository system. ${ }^{39}$ Hence, it is not surprising that no consistent purpose is reflected in depository operations. If free and equal access to essential government information is seen as a matter of governmental responsibility toward all citizens, it is necessary to determine just what information is covered and ensure its uniform availability. This raises the question of federal subsidies for depository operation. ${ }^{40}$ Based on the foregoing, there is a stronger case for expenditure of public funds on a defined and limited program of information availability than for the present diffuse subsidy to arbitrarily and accidentally selected libraries. If the depository system is meant to be a public subsidy to aid libraries to achieve their institutional goals, it is worthwhile to consider the advantages and disadvantages of free distribution of government publications as compared with federal payments to underwrite library purchases.

Replacing free or below-cost distribution with user charges and direct subsidy would encourage value comparisons between government information and nongovernmental alternatives. There is little doubt, for example, that the below-cost ERIC service is used in many research situations where it would not be chosen on grounds of suitability alone. The greatest economy for taxpayers is achieved when each dollar is spent where it brings the maximum return, and rational choice is possible only when prices correspond to costs.

Direct subsidy also has the advantage of confining the public payment to those for whom the benefit is intended. Under conditions of free or below-cost availability, commercial users of census data are subsidized to the same extent as local governments. Medline is available at the same low rates to the pharmaceutical industry as to medical schools and hospitals. Situations such as these suggest the possibility of differential pricing. This pricing could range from full subsidy to full cost recovery for different classes of users. Questions to be considered are (1) whether the same subsidy for all users is warranted in terms of the social ends to be served, and (2) whether prospective revenues would repay the cost of maintaining a differential price structure.

Differential pricing might also be used in situations where distribution of government information is contracted out to private firms. A condition of such contracts could be extension of free or below-cost access to favored users, such as libraries or universities. In that case the subsidy would be at the expense of the full-cost users of the information rather than the public, a practice that could be justified as partial repayment of the public investment in producing the information.

Economic and equity considerations aside, hidden subsidies in the form of free or below-cost distribution may be easier to achieve politically than direct payments or differential pricing. This is a serious practical consideration, but it does not provide a moral or philosophical basis for a general stance on the issue of user charges.

\section{CONCLUSIONS}

Viewing federal information from the perspective of economic propositions about public expenditure offers ways of focusing on specific purposes and outcomes of government information activities. Perhaps the principal conclusion to emerge is that it is seldom, if ever, practical to generalize about government information and government publications. Any generalization necessarily rests on assumptions concerning the information's origins, purposes, and uses. It is valid only to the extent that the assumptions apply. As reported by the Public Sector/Private Sector Task Force of the National Commission on Libraries and Information Science:

Most of the Task Force deliberations focused on the availability of "government information," but the definition of the term fluctuated widely during the discussion. . . . (U)sers interpret the term to mean what they want (or, in some cases, don't want) the term to cover. ${ }^{41}$ 
The preceding discussion has shown that virtually all of the values and principles invoked to support one or another position in the information debate-open government, economic justice, free enterprise tradition-are valid with reference to some government information activities and are questionable or irrelevant in other contexts. The heat and acrimony of the documents debate are generated by extending, to the topic as a whole, assumptions and arguments that are relevant only to selected aspects.

Another pervasive theme is that virtually any decision concerning government information is a decision about the expenditure of public funds. Policy choices are always tradeoffs, in which certain values are gained and others sacrificed. The precept that "government has a responsibility to make available the information collected and created by it ${ }^{\prime \prime 2}$ addresses only one side of the equation, an imbalance that can lead to quite irrational results. For example, GPO now distributes reprints of articles from commercial journals written by scientists employed by federal agencies to depository libraries. ${ }^{43}$
This absurdly wasteful practice is admittedly an extreme case, but it is mentioned here to underscore a basic point: the dissemination of government information at public expense should not be automatically assumed to be in "the public interest."

Opposition to the restrictive tendencies of the Reagan administration and the commercial self-interest of the information industry is natural and justified for librarians. That need not mean unyielding defense of the status quo or rejection of economic reality. The economic perspective outlined here suggests a way to replace global and unenlightening concepts such as the public interest with consideration of specific ends, means and side effects, based on recognition that every public policy choice entails gains and losses for someone. There are no single, universally correct answers to the central questions enumerated at the start of this paper, but there can be a critical, balance sheet orientation, assessing the available choices in terms of who gains, who loses, what, and how much.

\section{REFERENCES AND NOTES}

1. American Library Association, Washington Office, "Less Access to Less Information by and about the U.S. Government: A 1981-1984 Chronology, April 1981-December 1984," reprinted in Special Libraries 76:138-55 (Spring 1985).

2. The Freedom Of Information Act (5 U.S.C. 552) establishes a legal right of access to government records. A general assumption that government information should be available to the public is reflected in the history of depository library legislation. See Bernard M. Fry, Government Publications: Their Role in the National Program for Library and Information Services (Washington, D.C.: National Commission on Libraries and Information Science, 1978), p.45-47, and U.S. Congress, Joint Committee on Printing, Government Depository Libraries: The Present Law Governing Designated Depository Libraries (Washington, D.C.: Govt. Print. Off., 1984), p.1.

3. American Library Association, "Less Access" (Introduction). Similar statements appear in several resolutions of the ALA Council: 1984-85 Council Document no.47.3, 1983-84 C.D. no.31.6 and no.31.7, 1981-82 C.D. no.71.2, resolution entitled "Restrictions on Access to Government Information," adopted July 14, 1982.

4. U.S. Children, Youth and Families Administration, Infant Care, rev. ed. (Washington, D.C.: Govt. Print. Off., 1980). Published in numerous editions by the Children's Bureau beginning in 1924.

5. Arthur M. Okun, Equality and Efficiency: The Big Tradeoff (Washington, D.C.: The Brookings Institution, 1975), p.6.

6. Ibid., p.13.

7. Ibid., p.16.

8. U.S. Congress, Joint Committee on Printing, Federal Government Printing and Publishing: Policy Issues (Washington, D.C.: Govt. Print. Off., 1979), p.63.

9. For example, Marc A. Levin, "Access and Dissemination Issues Concerning Federal Government Information," Special Libraries 74:127-37 (Apr. 1983), p.136. 
10. With minor variations in classification and terminology, the account of basic economic principles presented here is common in the economic literature. The sources principally relied on are Robert Dorfman, ed., Measuring Benefits of Government Investments (Washington, D.C.: The Brookings Institution, 1965); Robert H. Haveman, The Economics of the Public Sector (New York: Wiley, 1970); Fritz Machlup, Knowledge and Knowledge Production (Princeton, N.J.: Princeton Univ. Pr., 1980); Richard A. Musgrave, The Theory of Public Finance: A Study in Public Economy (New York: McGrawHill, 1959); Gordon Tullock, Private Wants, Public Means: An Economic Analysis of the Desirable Scope of Government (New York: Basic Books, 1970).

11. Government intervenes also for purposes of economic stabilization, but that is largely irrelevant to the purpose here.

12. Rudolph A. Oswald, "Should the Government Collect Wage and Industrial Relations Statistics," in U.S. Congress, House Committee on Government Operations, OMB's Proposed Restrictions on Information Gathering and Dissemination By Agencies, Hearing July 17, 1985 (Washington, D.C.: Govt. Print. Off., 1985), p.24-34; Karen Pennar, "Does Anybody Really Know How the Economy Is Doing?" Business Week, May 6, 1985, p.128-32.

13. U.S. Congress, House Committee on Government Operations, Government Provision of Information Services in Competition with the Private Sector, Hearing February 25, 1982 (Washington, D.C.: Govt. Print. Off., 1982), p.42.

14. Ibid., p.136, 144.

15. Markley Roberts, in OMB's Proposed Restrictions, p.12.

16. "Privatization Holds Government Information Hostage," American Libraries 16:509 (July/Aug. 1985); OMB's Proposed Restrictions, p.173.

17. Bernard M. Fry, Government Publications, p.6; compare Peter Hernon and Charles R. McClure, Public Access to Government Information: Issues, Trends and Strategies (Norwood, N.J.: Ablex, 1984), p.14, 19.

18. American Library Association, "Less Access" (May 1982).

19. Robert Dorfman, Measuring Benefits, p.2.

20. Ruth P. Mack and Sumner Myers, "Outdoor Recreation," in Robert Dorfman, Measuring Benefits, p.83.

21. D. W. Pearce and C. A. Nash, The Social Appraisal of Projects: A Text in Cost-Benefit Analysis (New York: Wiley, 1981), p.17.

22. Robert Dorfman, Measuring Benefits, p.2.

23. U.S. Bureau of the Budget, Circular A-76, Revised, August 30, 1967 (Reprinted in U.S. Congress, House Committee on Post Office and Civil Service, Contracting Out of Jobs and Services, Hearings March 28 and 31, 1977, no.95-7 (Washington, D.C.: Govt. Print. Off., 1977), p.67-75.

24. Office of Management and Budget, "Management of Federal Information Resources," OMB Circular A-130, 7(e), 8.a. (11)(b). Federal Register 50:52732, 52736, 52748 (Dec. 24, 1985).

25. OMB Circular A-130, 7(e), 8.a. (9)(b), 8.a. (11)(b). Federal Register 50:52736, 52746, 52747 (Dec. 24, 1985).

26. OMB Circular A-130, 8.a. (11)(b). Federal Register 50:52736 (Dec. 24, 1985).

27. Government Provision of Information Services, p.7, 49, 70; Contracting Out of Jobs and Services.

28. John Jewkes, Public and Private Enterprise (Chicago: Univ. of Chicago Pr., 1965), p.10.

29. OMB Circular A-130, Appendix IV, 8.a. (11)(a). Federal Register 50:52748, (Dec. 24, 1985).

30. American Library Association, "Less Access" (February 1984).

31. Compare U.S. National Commission on Libraries and Information Science, Public Sector/Private Sector Task Force, Public Sector/Private Sector Interaction in Providing Information Services (Washington, D.C.: The Commission, 1982), p.66-67.

32. One-Hundred GPO Years 1861-1961: A History of United States Public Printing (Washington, D.C.: Govt. Print. Off., 1961) p.7-33.

33. Public Sector/Private Sector Interaction, p.34; Government Provision of Information Services, p.40-41, 71.

34. For an interesting explanation of the rational basis for governmental stodginess and inertia, see Arthur M. Okun, Equality and Efficiency, p.60-61.

35. Public Sector/Private Sector Interaction, p.ix; Marc A. Levin, "Access and Dissemination Issues," p.134; "Privatization Holds Government Information Hostage"; Jean Smith, "Information: Public or Private," Special Libraries 75:275-82 (Oct. 1984), p.280; Anita R. Schiller and Herbert I. Schiller, "Who Can Own What America Knows?" The Nation 234:461-3 (Apr. 17, 1982), p.461.

36. Bernard M. Fry, Government Publications, p.115; compare Public Sector/Private Sector Interaction, p.ix.

37. See, for example, Government Depository Libraries, p.1; American Library Association, 1983-84 Council Document no.31.7; Anita R. Schiller and Herbert I. Schiller, "Who Can Own What Amer- 
ica Knows," p.462-63; Jean Smith, "Information: Public or Private," p.279.

38. Bernard M. Fry, Government Publications, p.51.

39. LeRoy C. Schwarzkopf, "Depository Libraries and Public Access" in Peter Hernon, ed. Collection Development and Public Access of Government Documents (Westport, Conn.: Meckler, 1982), p.7-33.

40. Public Sector/Private Sector Interaction, p.53-54, 64; Bernard M. Fry, Government Publications, p.69; Federal Government Printing and Publishing, p.46.

41. Public Sector/Private Sector Interaction, p.19-20.

42. American Library Association, 1983-84 Council Document no.31.7.

43. For example, Daniel Dzurisin and others, "Magma Supply and Storage at Kilauea Volcano, Hawaii, 1956-1983," Journal of Volcanology and Geothermal Research 21:177-206 (1984), distributed as a "publication" of the U.S. Geological Survey in Jan. 1985 (I 19.2:M27/3). 